\title{
Spatiotemporal variations in mid-upper tropospheric methane over China from satellite observations
}

\author{
ZHANG Xing Ying $^{1,2^{*}}$, BAI WenGuang ${ }^{1}$, ZHANG Peng ${ }^{1} \&$ WANG WeiHe ${ }^{1}$ \\ ${ }^{1}$ Key Laboratory of Radiometric Calibration and Validation for Environmental Satellites, National Satellite Meteorological Center, China \\ Meteorological Administration, Beijing 100081, China; \\ ${ }^{2}$ State Key Laboratory of Atmospheric Boundary Layer Physics and Atmospheric Chemistry, Institute of Atmospheric Physics, Chinese Academy \\ of Sciences, Beijing 100029, China
}

Received February 17, 2011; accepted July 4, 2011; published online August 30, 2011

\begin{abstract}
Spaceborne measurements by the Atmospheric Infrared Sounder (AIRS) on the EOS/Aqua satellite provide a global view of methane $\left(\mathrm{CH}_{4}\right)$ distribution in the mid-upper troposphere $\left(\mathrm{MUT}-\mathrm{CH}_{4}\right)$. The focus of this study is to analyze the spatiotemporal variations in MUT-CH $\mathrm{CH}_{4}$ over China from 2003 to 2008. Validation of AIRS $\mathrm{CH}_{4}$ products versus Fourier transform infrared profiles demonstrates that its RMS error is mostly less than 1.5\%. A typical atmospheric methane profile is found that shows how concentrations decrease as height increases because of surface emissions. We found that an important feature in the seasonal variation in $\mathrm{CH}_{4}$ is the two peaks that exist in summer and winter in most parts of China, which is also observed in in-situ measurements at Mt. Waliguan, Qinghai Province, China $\left(36.2879^{\circ} \mathrm{N} 100.8964^{\circ} \mathrm{E}, 3810 \mathrm{~m}\right)$. Also, in the summer, only one peak existed in western and southern China since there are no more significant anthropogenic sources in winter than at any other time of the year. Further analysis of the deseasonalized time-series of AIRS $\mathrm{CH}_{4}$ in three fixed pressure layers of AIRS from 2003 to 2008 indicates that $\mathrm{CH}_{4}$ in the Northern Hemisphere has increased abruptly since 2007, with no significant increase occurring before 2007. The increase in China is generally more significant than in other areas around the world, which again correlates with in-situ measurements at Mt. Waliguan.
\end{abstract}

satellite remote sensing, mid-upper tropospheric methane, spatiotemporal variation

Citation: Zhang X Y, Bai W G, Zhang P, et al. Spatiotemporal variations in mid-upper tropospheric methane over China from satellite observations. Chinese Sci Bull, 2011, 56: 3321-3327, doi: 10.1007/s11434-011-4666-x

Atmospheric methane $\left(\mathrm{CH}_{4}\right)$ over the globe has risen dramatically since the pre-industrial era $[1,2]$. However, in recent years the rate of increase has not been so significant and even decreased in 1992 [3]. As one of the most important greenhouse gases, changes in atmospheric methane are very important for atmospheric chemical processes and climate change. Atmospheric methane accounts for about $20 \%$ of the total of $2.66 \mathrm{~W} \mathrm{~m}^{-2}$ of the anthropogenically produced greenhouse gas [4]. The mixing rate of atmospheric methane is less than that of carbon dioxide, but 25 times more effective on a per unit mass basis than carbon dioxide in absorbing long-wave radiation and its increase will affect the earth's radiation budget [5]. Atmospheric methane is

*Corresponding author (email: zxy@cma.gov.cn) one of the most important carbon compounds; it can change the concentrations of $\mathrm{OH}$ and $\mathrm{CO}$ and has an important role in the chemistry of $\mathrm{O}_{3}$ and $\mathrm{H}_{x} \mathrm{O}_{y}[6,7]$. However, much work is still needed to build on intermittent and scattered observations from the 1960s and a systematic study from the 1980s [7,8]. From 1983, the World Meteorological Organization (WMO) began to co-ordinate the global in-situ measurement of methane. Quantification of methane emissions still has large uncertainties, mainly due to undersampling over most regions of the globe by the surface observation network. Even the results of aircraft observations have low spatial and temporal distributions due to their collection method. Therefore, the information available for the precise measurement or modeling of global distributions of methane and its variability are still unclear [8-11]. 
In recent years, spaceborne remote sensing has been employed to measure $\mathrm{CH}_{4}$ with large spatial and temporal coverage, which can effectively compensate for the lack of surface observations [12]. Two major types of measurement are (1) the measurement of the total column using the nearinfrared spectrum and (2) the measurement of the mid-toupper troposphere methane (MUT- $\left.\mathrm{CH}_{4}\right)$ using the thermal infrared spectrum with bands of 7.66, 3.3 and $2.3 \mu \mathrm{m}$ [13-23]. One of the spaceborne thermal infrared sounders in operation, the Atmospheric Infrared Sounder (AIRS), was launched in polar orbit (13:30, ascending node) on the EOS/Aqua satellite in May 2002, $\mathrm{CH}_{4}$ is one of its research products $[13,14]$.

In this study, we validate the AIRS $\mathrm{CH}_{4}$ product versus Fourier transform infrared (FTIR) profiles and in-situ measurement in China and discuss the spatiotemporal variations in MUT- $\mathrm{CH}_{4}$ over China during 2003-2008.

\section{Data and methods}

\subsection{AIRS measurement of $\mathrm{CH}_{4}$}

AIRS was launched in polar orbit (at 13:30 local time, ascending node) on the EOS/Aqua satellite on 4 May 2002. It has high spectral resolution $(\lambda \backslash \lambda=1200)$, and low noise [17]. The spatial resolution of AIRS is $13.5 \mathrm{~km}$ at nadir, and the swath width is $1650 \mathrm{~km}$. Scan angles range from $-49.5^{\circ}$ to $49.5^{\circ}$, IFOV (instantaneous field of view) is 1.10 , and in a $24-\mathrm{h}$ period AIRS normally completely observes the globe twice.

The mixing rate of $\mathrm{CH}_{4}$ data used in this study was downloaded from NASA (http://disc.sci.gsfc.nasa.gov). It includes three layer products with the maximum sensitive layer of AIRS (407.25, 306.75 and $206.25 \mathrm{hPa})$. The singular value decomposition method was used for $\mathrm{CH}_{4}$ retrieval based on the $7.66 \mu \mathrm{m}$ band with high spectra resolution [13-18]. Validation using in situ aircraft observations from 2003 to 2006 showed that the bias of the retrieved $\mathrm{CH}_{4}$ profiles is approximately $-1.4 \%$ to $0.1 \%$ and its root mean square (RMS) difference is about $0.5 \%-1.6 \%$ [13]. Validation of $\mathrm{MUT}-\mathrm{CH}_{4}$ using aircraft measurements from NOAA/ESRL/GMD and NASA Intercontinental Chemical Transport Experiment phases A and B demonstrated that in the HNH (high Northern Hemisphere) the RMS error of AIRS MUT-CH $\mathrm{CH}_{4}$ is less than $1.2 \%$, and the correlation coefficient between the AIRS MUT- $\mathrm{CH}_{4}$ and aircraft measurements is about $0.6-0.7$ [16]. This product has been used for the analysis of the variability and transport of atmospheric methane $[16,17]$.

\subsection{Ground-based measurement of $\mathrm{CH}_{4}$}

In situ $\mathrm{CH}_{4}$ mixing ratio data from the MBL (mixed binding layer) were collected at Mt. Waliguan, Qinghai Province, China $\left(36.2879^{\circ} \mathrm{N} 100.8964^{\circ} \mathrm{E}\right)$. The data were measured based on the GAW (Global Atmosphere Watch) standard from 1994 [24-26] and were shown to be of high quality $[27,28]$. In this work the data from Mt. Waliguan was compared with the AIRS $\mathrm{CH}_{4}$ data.

FTIR measurements were carried out at a ground-based hyperspectral remote sensing laboratory located at the $\mathrm{Na}$ tional Satellite Meteorological Center. The Bruker FTIR instrument (IFS 120 M, which made in Ettlingen of German) was used for observations. The specifications for atmospheric spectrum measurements are based on the Network for the Detection of Atmospheric Composition Change [29,30]. Observation of greenhouse gases has been carried out for several years [31].

\section{Results and discussion}

\subsection{Validation of AIRS $\mathrm{CH}_{4}$ measurements}

In situ measurements of $\mathrm{CH}_{4}$ from Mt. Waliguan were used for comparison with AIRS $\mathrm{CH}_{4}$, which is generated by the flask method twice a week based on the cooperation of NOAA-CMDL and CAMS. Figure 1 shows the comparison

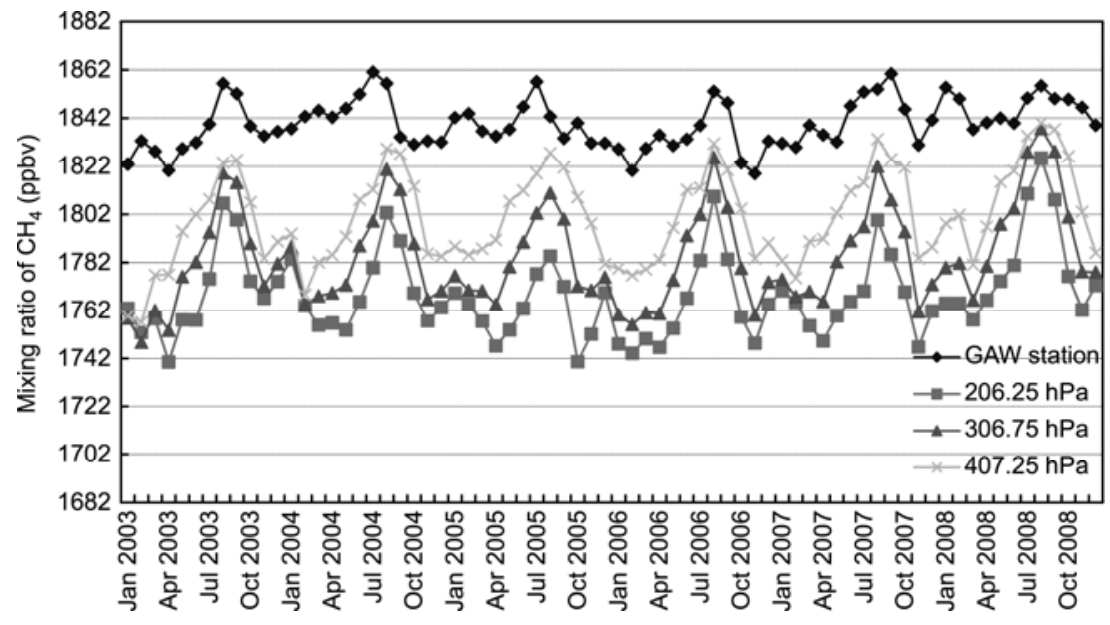

Figure 1 Comparison of AIRS $\mathrm{CH}_{4}$ products and in-situ measurements from Mt. Waliguan. 
of in situ data and AIRS products. It can be seen clearly that the seasonal cycle of AIRS is similar to that of in-situ measurements. $\mathrm{CH}_{4}$ concentrations decreased with an increase in height.

The $\mathrm{CH}_{4}$ profile data from ground-based remote sensing by FTIR also was used to quantitatively validate AIRS $\mathrm{CH}_{4}$ measurements (Figure 2). FTIR measurements were made at the National Satellite Meteorological Center in Beijing from January to June, 2009. The results show that the AIRS retrieval products at three different heights is very close to the results from ground based measurement. The bias is $0.2 \%-$ $1.1 \%$, which is similar to aircraft validation results $(0.5 \%-$ $1.6 \%)[13]$.

\subsection{Spatial distribution of $\mathrm{CH}_{4}$ over China}

Average distributions of $\mathrm{CH}_{4}$ at a range of heights over China are shown in Figure 3. The $\mathrm{CH}_{4}$ mixing ratio in the middle of the troposphere $(407.25 \mathrm{hPa})$ is higher than that in the upper troposphere and at the top of the troposphere because of emission in the boundary layer. The highest $\mathrm{CH}_{4}$ concentrations exist in the middle of the troposphere over the east, northeast, and south of China and cities in the north-

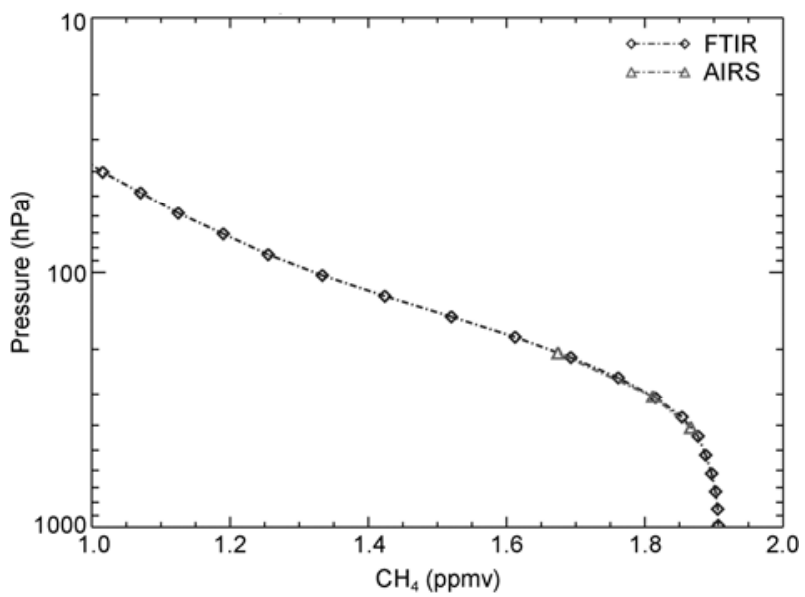

Figure 2 Averaged $\mathrm{CH}_{4}$ products from FTIR and AIRS from January to June, 2009. west. This is associated with rice paddy and swamp emissions. The $\mathrm{CH}_{4}$ mixing ratio is higher on the coast than that over the ocean because of the frequency of air exchange between the mainland and proximal marine environments. Low $\mathrm{CH}_{4}$ concentrations are found on the Qinghai-Tibetan Plateau in the west of China as a result of the high altitude and minimal human activity. However, the highest $\mathrm{CH}_{4}$ mixing ratios in the upper-middle and top of the troposphere are in areas of inland China, Inner Mongolia and Shenyang. Also, low $\mathrm{CH}_{4}$ mixing ratios likely exist in southeastern China because of the effect of the marine environment.

Figure 4 shows the monthly variation in $\mathrm{CH}_{4}$ over five different areas in China (Northeast: $42^{\circ}-48^{\circ} \mathrm{N}, 120^{\circ}-128^{\circ} \mathrm{E}$; Northwest: $40^{\circ}-44^{\circ} \mathrm{N}, 80^{\circ}-92^{\circ} \mathrm{E}$; East: $30^{\circ}-40^{\circ} \mathrm{N}, 108^{\circ}-$ $118^{\circ} \mathrm{E}$; West: $30^{\circ}-38^{\circ} \mathrm{N}, 88^{\circ}-100^{\circ} \mathrm{E}$; South: $22^{\circ}-26^{\circ} \mathrm{N}$, $\left.104^{\circ}-116^{\circ} \mathrm{E}\right) . \mathrm{CH}_{4}$ concentrations decrease with an increase in height. The lowest $\mathrm{CH}_{4}$ mixing ratio at the top of the troposphere is in southern China. Also, in the upper troposphere, $\mathrm{CH}_{4}$ mixes well in all regions. In the middle troposphere, a low $\mathrm{CH}_{4}$ concentration center is located over western China due to the minimal occurrence of industrial and agricultural activities.

\subsection{Seasonal cycle of $\mathrm{CH}_{4}$ over China}

The seasonal cycle of $\mathrm{CH}_{4}$, averaged from 2003 to 2008 in different areas of China, is shown in Figure 5.

Two peaks are apparent in summer and winter over eastern, northeastern and northwestern China, which is consistent with the in-situ measurement for Mt. Waliguan [32]. Only one peak (in summer) occurs over southern and western China.

The reason for the two peaks of $\mathrm{CH}_{4}$ over certain areas of China is related to $\mathrm{CH}_{4}$ from biological and non-biological sources. The winter peak might be caused by $\mathrm{CH}_{4}$ emission from fossil fuels burned for central heating in houses in the north of China. Also, the weather conditions in winter are conducive to the accumulation of pollutants. The summer peak may correspond to the most productive period of biological $\mathrm{CH}_{4}$ emissions. Rice paddies, rivers and lakes are important $\mathrm{CH}_{4}$ sources. Previous studies show that the
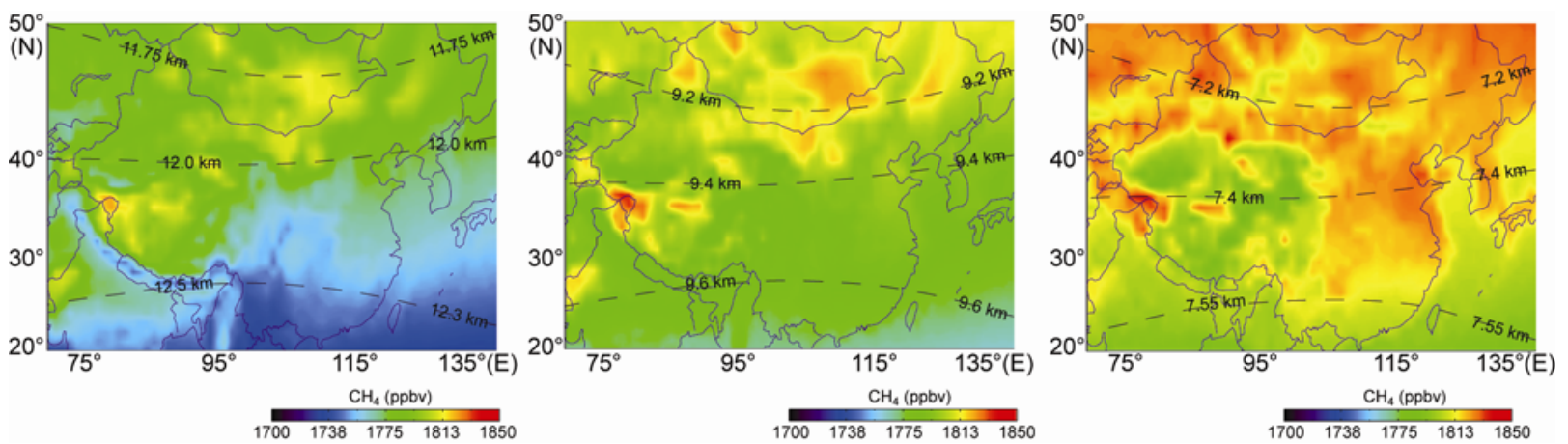

Figure 3 Distribution of average troposphere $\mathrm{CH}_{4}$ over China from 2003 to 2008 (Left to right: 206.25, 306.75, 407.25 hPa). 

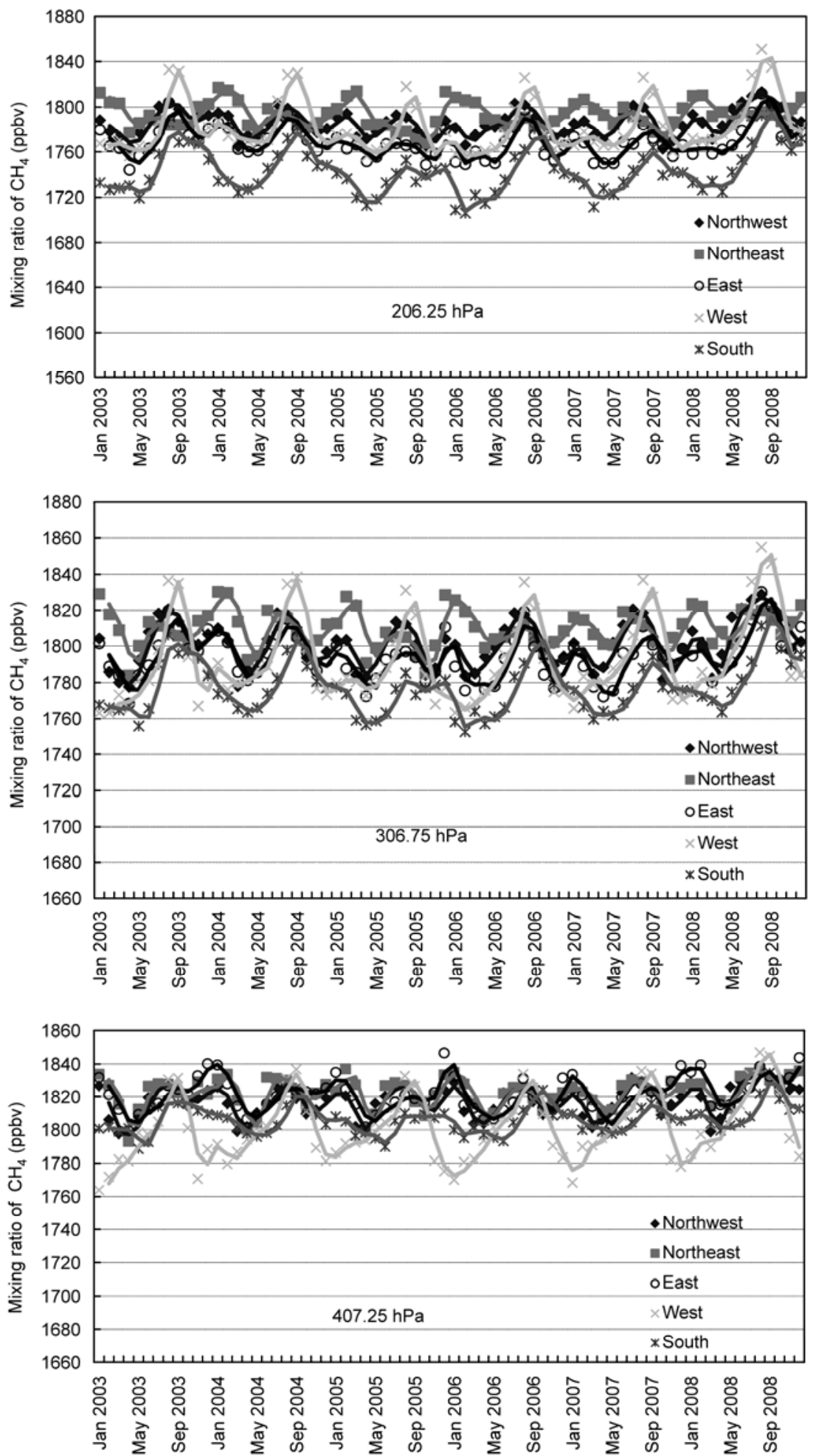

Figure 4 Monthly concentrations of $\mathrm{CH}_{4}$ for different areas (as indicated) over China.

emission of $\mathrm{CH}_{4}$ is closely related to temperature. There is little $\mathrm{CH}_{4}$ emission from rice paddies, rivers and lakes when the temperature is lower than $15^{\circ} \mathrm{C}$, whereas much more $\mathrm{CH}_{4}$ is emitted at temperatures of $35^{\circ} \mathrm{C}$ than in $25^{\circ} \mathrm{C}$ [33-39]. Waste decomposition is another important biological source of methane. As cities expand and population grows, the organic waste in landfills decomposes and produces more and more $\mathrm{CH}_{4}$. In the southern region of China, the significant anthropogenic sources of methane do not vary with season because there is not the same need for heating 

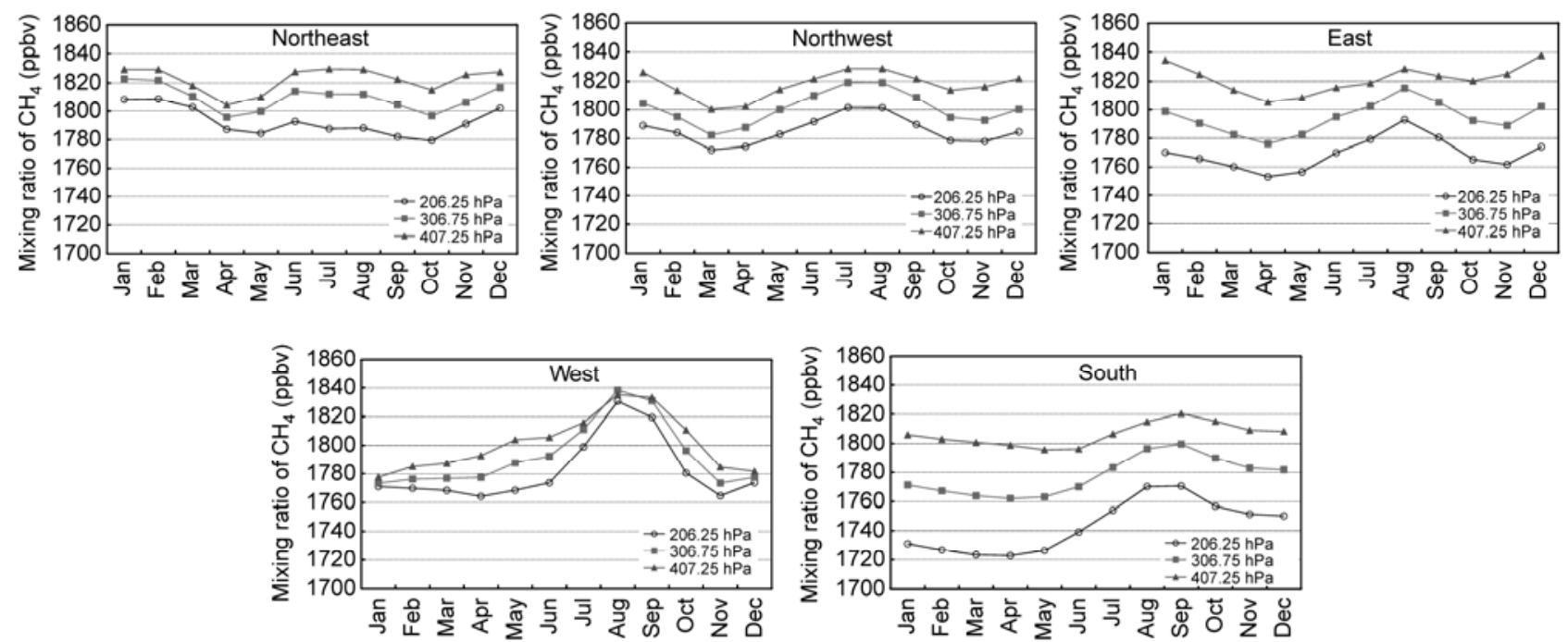

Figure 5 Seasonal variation in $\mathrm{CH}_{4}$ averaged from 2003 to 2008 in different areas over China.

systems in winter. In the sparsely populated western region of China, there are few anthropogenic sources of $\mathrm{CH}_{4}$ from industry and biological emissions are the main source of $\mathrm{CH}_{4}$. In the summer, the high temperature and humid environment is conducive to $\mathrm{CH}_{4}$ production, because abundant $\mathrm{CH}_{4}$ comes from the decomposition of organic soil matter and can be released to the atmosphere. In colder periods, biologically sourced contributions to $\mathrm{CH}_{4}$ emission are greatly decreased. Thus the lowest $\mathrm{CH}_{4}$ mixing ratios occur in the winter in western China. Note that the seasonal cycle of methane based on AIRS observations is dependent on the methane emissions from sources and closely related to the ability of the atmosphere to transport them.

\subsection{Long-term $\mathrm{CH}_{4}$ trends over China}

Figure 6 shows the variation in $\mathrm{CH}_{4}$ mixing ratios in the troposphere over seven areas around the world from 2003 to 2008. A significant increase in $\mathrm{CH}_{4}$ concentrations in the troposphere after 2007 can be found in most areas of the Northern Hemisphere. However, before 2007, the $\mathrm{CH}_{4}$ mixing ratio is almost stable. That said, the $\mathrm{CH}_{4}$ mixing ratio does show a slightly decreasing trend over Australia (in the southern hemisphere) before 2007 and then starts to grow. This conclusion is consistent with previous studies [15]. The average methane mixing ratio during the last 6 years over China is comparable with those of other countries in the Northern Hemisphere. Table 1 shows the difference in methane concentration between 2008 and the mean of 2003-2007 for six areas around the world. The most significant increases are found in China, followed by the United States and Canada. Note that $\mathrm{CH}_{4}$ concentrations in Australia show a slight downward trend before 2007 and then start to growth in 2008. This conclusion is consistent with in-situ measurements [40-43]. Table 2 shows $\mathrm{CH}_{4}$ growth rates in different layers of the troposphere over China from
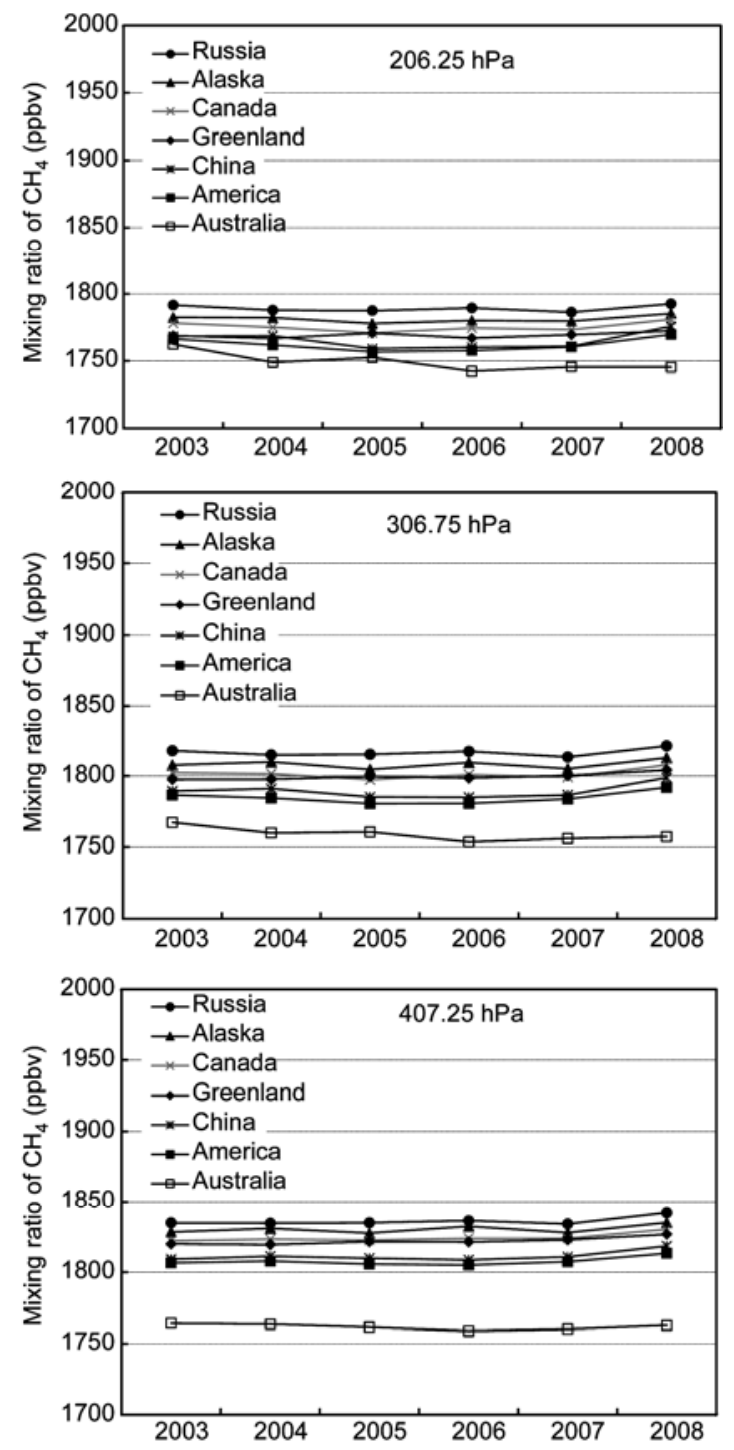

Figure 6 Tropospheric $\mathrm{CH}_{4}$ growth rates for various sites around the world (2003-2008). 
Table 1 Methane concentration differences between 2008 and the 2003-2007 average for typical areas

\begin{tabular}{lccccc}
\hline \multirow{2}{*}{ Area } & Latitude & Longitude & \multicolumn{3}{c}{ Methane concentration differences (ppbv) } \\
\cline { 4 - 6 } & & & $206.25 \mathrm{hPa}$ & $306.75 \mathrm{hPa}$ & $406.25 \mathrm{hPa}$ \\
\hline China & $22^{\circ}-42^{\circ} \mathrm{N}$ & $120^{\circ}-120^{\circ} \mathrm{E}$ & 12.4 & 11.3 & 8.5 \\
America & $33^{\circ}-45^{\circ} \mathrm{N}$ & $130^{\circ}-90^{\circ} \mathrm{W}$ & 9.1 & 8.7 & 6.7 \\
Canada & $50^{\circ}-65^{\circ} \mathrm{N}$ & $163^{\circ}-142^{\circ} \mathrm{W}$ & 6.6 & 7.4 & 7.0 \\
Alaska & $60^{\circ}-70^{\circ} \mathrm{N}$ & $45^{\circ}-135^{\circ} \mathrm{E}$ & 4.9 & 5.5 & 5.6 \\
Russia & $55^{\circ}-70^{\circ} \mathrm{N}$ & $50^{\circ}-20^{\circ} \mathrm{W}$ & 3.0 & 5.4 & 7.0 \\
Granada & $65^{\circ}-80^{\circ} \mathrm{N}$ & $120^{\circ}-150^{\circ} \mathrm{E}$ & -4.9 & -2.1 & 5.7 \\
Australia & $30^{\circ}-20^{\circ} \mathrm{S}$ & & & & 1.2 \\
\hline
\end{tabular}

Table $2 \mathrm{CH}_{4}$ mixing ratio growth rate over China from 2006 to 2008

\begin{tabular}{ccccc}
\hline \multirow{2}{*}{$\begin{array}{c}\text { Altitude } \\
(\mathrm{hPa})\end{array}$} & \multicolumn{3}{c}{ Methane concentration (ppbv) } & Growth rate \\
\cline { 2 - 4 }$(\mathrm{ppbv/a)}$
\end{tabular}

2006 to 2008 . The annual mean growth rate is 5-8 ppbv/a, which is similar to the Mt. Waliguan in-situ measurement (6.8 ppbv/a). However, in-situ measurements show that the $\mathrm{CH}_{4}$ mixing ratio starts to growth significantly from 2006, which is a year earlier than the satellite result (i.e. starting in 2007). Note that the trend of $\mathrm{CH}_{4}$ based on satellite observation still has some uncertainties with the 6-year average data. More data are needed for further trend analysis.

\section{Conclusions}

In this study, AIRS data were used to study the spatiotemporal distribution of $\mathrm{CH}_{4}$ over China. The primary conclusions are as follows.

(1) Validation with ground-based measurements demonstrated that the retrieval RMS errors of AIRS $\mathrm{CH}_{4}$ are mostly less than $1.5 \%$, which proves that the AIRS product can be used for distribution analysis.

(2) Methane mixing ratios over China decrease with an increase in height because of the effects of human activities and natural emission of $\mathrm{CH}_{4}$ from the boundary layer.

(3) Obvious bimodal seasonal variations in $\mathrm{CH}_{4}$ concentrations exist in most areas of China, with the highest values in summer and the second highest in winter. Only the summer peak occurs in the western and southern areas of China.

(4) The mixing ratio of MUT- $\mathrm{CH}_{4}$ is relatively stable before 2007 over several main regions of the Northern Hemisphere (including China). Significant growth is found after 2007, with China having the highest growth rate.
We thank NASA for the AIRS data. This work was supported by the National Natural Science Foundation of China (40905056), the Public Industry-specific Fund for Meteorology (GYHY201106045) and the State Key Laboratory of Atmospheric Boundary Layer Physics and Atmospheric Chemistry (LAPC-KF-2008-11).

1 Gunter W D, Wong S, Cheel D B, et al. Slowing down of the global accumulation of atmospheric methane during the 1980s. Nature, 1992, 358: 313-316

2 Khalil M A K, Rasmussen R A. Atmospheric methane trends over the last 10000 years. Atmos Environ, 1984, 21: 2445-2452

3 Dlugokenky E J, Steele L P, Lang P M, et al. The growth rate and distribution of atmospheric methane. J Geophys Res, 1994, 99: 1702117043

4 Etheridge D M, Pearman G I, Fraser P J. Changes in tropospheric methane between 1841 and 1978 from a high accumulation-rate Antarctic ice core. Tellus, 1992, 44B: 282-294

5 IPCC. Climate Change 2007: The Physical Science Basis, Contribution of Working Group I to the Fourth Assessment Report of the Intergovernmental Panel on Climate Change. Cambridge: Cambridge University Press, 2007. 500-590

6 Grutzen P J. On the role of $\mathrm{CH}_{4}$ in atmospheric chemistry: Sources, sinks and possible reductions in anthropogenic sources. Ambio, 1995, 24: $52-55$

7 Tang X Y. Atmosphere Environmental Chemistry (in Chinese). Beijing: Higher Education Press. 1990. 48-51, 305-306

8 Zhou L X. Green-house distribution character over China (in Chinese). Master's Thesis. Beijing: Environmental Sciences Center, Peking University. 2001

9 Zhou L X, Tang J, Wen Y P, et al. Characters of atmospheric methane concentration at Mt.Waliguan (in Chinese). Appl Meteorol, 1998, 9: 385-391

10 WMO. Strategy for the Implementation of the Global Atmosphere Watch Program (2001-2007), a contribution to the implementation of the WMO long-term plan. Geneva, Switzerland, GAW Report, 2001, 142: $1-21$

11 Zhou L X, Tang J, Zhang X C, et al. In-situ gas chromatographic measurement of atmospheric methane and carbon dioxide (in Chinese). Acta Sci Circums, 1998, 18: 356-361

12 Zhang X Y, Zhang P, Fang Z Y, et al. The progress in trace gas remote sensing study based on the satellite monitoring (in Chinese). Meteorol Monthly, 2007, 33: 1-14

13 Xiong X, Barnet C, Maddy E, et al. Characterization and validation of methane products from the Atmospheric Infrared Sounder (AIRS). J Geophys Res, 2008, 113: G00A01, doi: 10.1029/2007JG000500

14 Xiong X, Barnet C, Wei J, et al. Information-based mid-upper tropospheric methane derived from Atmospheric Infrared Sounder (AIRS) and its validation. Atmos Chem Phys Discuss, 2009, 9: 16331-16360

15 Xiong X, Barnet C D, Maddy E, et al. Seven years' observation of mid-upper tropospheric methane from atmospheric infrared sounder. 
Remote Sensing, 2010, 2: 2509-2530

16 Xiong X, Houweling S, Wei J, et al. Methane plume over south Asia during the monsoon season: Satellite observation and model simulation. Atmos Chem Phys, 2009, 9: 783-794

17 Xiong X, Barnet C, Zhuang Q, et al. Mid-upper tropospheric methane in the High Northern Hemisphere: Space-borne observations by AIRS, Aircraft Measurements and Model Simulations. J Geophys Res, 2010, 115: D19309, doi:10.1029/2009JD013796.

18 Susskind J, Barnet C D, Blaisdell J M. Retrieval of atmospheric and surface parameters from AIRS/AMSU/HSB data in the presence of clouds. IEEE T Geosci Remote, 2003, 41: 390-409

19 De M, Vigouroux C, Bernath, et al. Validation of ACE-FTS v2.2 methane profiles from the upper troposphere to the lower mesosphere. Atmos Chem Phys, 2008, 8: 2421-2435

20 Frankenberg C, Meirink J F, van Weele, et al. Assessing methane emissions from global space-borne observations. Science, 2005, 308: 1010-1014

21 Payan S, Camy-Peyret C, Oelhaf H, et al. Validation of version-4.61 methane and nitrous oxide observed by MIPAS. Atmos Chem Phys, 2009, 9: 413-442

22 Payne V H, Clough S A, Shephard M W, et al. Information centered representation of retrievals with limited degrees of freedom for signal: Application to methane from the Tropospheric Emission Spectrometer. J Geophys Res, 2009, 114: D1030

23 Crevoisier C, Nobileau D, Fiore A M, et al. A new insight on tropospheric methane in the Tropics-first year from IASI hyperspectral infrared observations. Atmos Chem Phys Discuss, 2009, 9: 6855-6887

24 WMO. International Operations Handbook for Measurement of Background Atmospheric Pollution. WMO TD491, Geneva, Switzerland, 1978

25 WMO. The Global Atmosphere Watch Guide. GAW No.86, WMO TD553, Geneva, Switzerland, 1993

26 Zhou X J. Summery Report to the Progress of China Ground Observation (1994-2004) (in Chinese). Beijing: China Meteorological Administration, 2005. 98

27 WMO. The state of greenhouse gases in the atmosphere using global observations through 2006. Greenhouse Gas Bull, 2007

28 Zhang D Q, Zhang X C, Nie H, et al. Quality control of $\mathrm{CO}_{2}$ and $\mathrm{CH}_{4}$ measurement data on China global atmosphere watch baseline observatory (in Chinese). Appl Meteorol, 2004, 12: 95-100

29 Dils B, De Mazière M. Müller J F, et al. Comparisons between SCIAMACHY and ground-based FTIR data for total columns of CO,
$\mathrm{CH}_{4}, \mathrm{CO}_{2}$ and $\mathrm{N}_{2} \mathrm{O}$. ACP, 2006, 6: 1953-1976

30 Hase F, Hannigan J W, Coffey M T, et al. Intercomparison of retrieval codes used for the analysis of high-resolution, ground-based FTIR measurements. J Quant Spect Rad Trans, 2004, 87: 25-52

31 Zhang X Y, Zhang P, Fang Z Y, et al. On ground-based remote sensing for atmospheric species by FTIR (in Chinese). Inst Ret Algo Meteorol Monthly, 2009, 35: 9-17

32 Henckel T, Roslev P, Conrad R. Effects of $\mathrm{O}_{2}$ and $\mathrm{CH}_{4}$ on presence and activity of the indigenous methanotrophic community in rice field soil. Environ Microbiol, 2000, 2: 666-679

33 Yagi K, Minami K. Effect of organic matter applications on methane emission from some Japanese paddy fields. Soil Sci Plant Nutr, 1990, 36: 599-610

34 Thomas K L, Benstead J, Davies K L, et al. Role of wetland plants in the diurnal control of $\mathrm{CH}_{4}$ and $\mathrm{CO}_{2}$ fluxes in peat. Soil Biol Biochem, 1996, 28: 17-23

35 Holzapfel-Pschorn A, Conrad R, Seiler W. Effects of vegetation on the emission of methane from submerged paddy soil. Plant Soil, 1986, 92: 223-233

36 Khalil M A K, Rasmussen R A, Mingxing W, et al. Methane emission from rice field in China. Environ Sci Technol, 1991, 25: 979981

37 Saarnio S, Alm J, Martikainen P J, et al. Effects of raised $\mathrm{CO}_{2}$ on potential $\mathrm{CH}_{4}$ production and oxidation in, and $\mathrm{CH}_{4}$ emission from a boreal mire. J Ecol, 1998, 86: 261-268

38 Saarnio S, Silvola J. Effect of increased $\mathrm{CO}_{2}$ and $\mathrm{N}$ on $\mathrm{CH}_{4}$ efflux from boreal mire: A growth chamber experiment. Oecologia, 1999, 119: 349-356

39 Saarnio S, Saarinen T, Vasander H, et al. A moderate increase in the annual $\mathrm{CH}_{4}$ efflux by raised $\mathrm{CO}_{2}$ or $\mathrm{NH}_{4} \mathrm{NO}_{3}$ supply in boreal oligotrophic mire. Glob Change Biol, 2000, 6: 137-144

40 Global View- $\mathrm{CH}_{4}$, Cooperative Atmospheric Data Integration Project2Methane. NOAA CMDL Data Product and Report, Boulder, Colorado, USA. 2005

41 Rigby M, Prinn R G, Fraser P J, et al. Renewed growth of atmospheric methane. Geophys Res Lett, 2008, 35: L22805, doi: 10.1029/ 2008GL036037

42 Dlugokencky E J, Bruhwiler L, White J W C, et al. Observational constraints on recent increases in the atmospheric $\mathrm{CH}_{4}$ burden. Geophys Res Lett, 2009, 36: L18803, doi:10.1029/2009GL039780

43 Global VIew- $\mathrm{CH}_{4}$. Cooperative Atmospheric Data Integration Project-Methane, Boulder, CO, USA, 2009: NOAA ESRL

Open Access This article is distributed under the terms of the Creative Commons Attribution License which permits any use, distribution, and reproduction in any medium, provided the original author(s) and source are credited. 